\title{
Contribution of Statistical Analysis Methods to Assessment of the Physicochemical Quality of the Dam
}

\author{
Aissam Gaagai*, Hani Amir Aouissi, Salah Eddine Maalam and Mostefa Ababsa \\ Scientific and Technical Research Center on Arid Regions (CRSTRA). Biskra, 07000, Algeria
}

*Corresponding author: Aissam GAAGAI, Scientific and Technical Research Center on Arid Regions (CRSTRA). Biskra, 07000, Algeria..

Received Date: September 22, 2020

Published Date: October 20, 2020

\begin{abstract}
We used statistical analysis to try to evaluate the temporal variations concerning surface water located in Baber watershed. So, we collected twenty-one (21) samples, for each city, seven (7) ones were collected. In these samples, we determined eleven (11) physicochemical parameters. Concerning the eastern part (S1): the salinity of samples proves high TDs values, while low TDs levels were found in the west $\left(\mathrm{S}_{2}\right)$. In the dam $\left(\mathrm{S}_{3}\right)$ TDs values are considered as intermediate on average. Regarding the water type: It wasSO4-Na in S1, $\mathrm{HCO}_{3}$-Ca-Mg in $\mathrm{S}_{2}$ and finally SO4-Ca-Mgin the dam (S3) which characterizes mixed water. In R-mode, Cluster analysis was used; we classified seven (7) variables into two (2) clusters which are controlled by S04.About Q-mode, 21 samples were grouped into three (3) groups corresponding to our three (3) stations: S1, S2 and S3. Factor analysis is indicating to us two factors: these factors explains $87 \%$ of the total variance related with data set about water quality. We have two factors (Salinization and sulfates) that explain respectively $73 \%$ and $14 \%$ of the total variance. We noticed by relying on time series analysis that $\mathrm{Cl}$, $\mathrm{Na}, \mathrm{Mg}$, Ca and SO4 have very similar trend with TDs, and we noticed similar pattern between K and NO3. It suggests that five (5) components are controlling the evolution of TDs. Negative correlations between K \& No3 with TDs because of human activities, like domestic sewages (thrown into the tributaries of Wadi Arab) and fertilizers for example. We could notice, by establishing this study, the real benefit of the used technique (statistical analysis) to interpret complex data sets related to the analysis of spatio-temporal variations in the water surface's quality.
\end{abstract}

Keywords: Statistical analysis; Salinization; Surface water; Dam; Baber

\section{Introduction}

Most people in the world do not have access to safe drinking water, which has led to an increase in water-borne diseases [1]. water used for consumption must be potable. Drinking water is water that is free of diseases that produce micro-organisms and chemicals that are dangerous to health [2]. Water consists of different soluble salts and the quality of drinking water is affected by the presence of these different soluble salts [3]. Surface water quality is mainly influenced by the nature and anthropogenic processes especially in urban areas and agricultural activities around rural areas [4]. These anthropogenic processes lead to the contamination of water. Contaminated water not only affects the health of the public, but also the consumption of polluted water can cause various waterborne diseases such as diarrhea, dysentery and complaints of skin, teeth and other abdominal diseases [5]. Transmission of the disease by drinking water is therefore one of the main concerns for drinking water supply [6]. World demand for water remains mainly growing due to population growth, economic growth, rapid urbanization and increasing demand for food and energy [7]. Therefore, assessing the availability of water resources at the relevant spatial and temporal scales is important [8], as well as the ability to assess the availability of freshwater resources has been a question of importance in most countries for several decades [9].

The main objective of this present work is the characterization of the chemistry of surface water, and the determination of the or- 
igin of chemical elements founded by using two techniques: time series analysis and the multivariate statistical techniques. Our investigation area is located in Algerian South-East. The vast majority of inhabitants (more than 20,000) are concentered in the town of Baber.

\section{Materials and Methods}

\section{Study area}

The study area is located at the downstream of the Wadi (River) Arab. The area of the watershed is $567 \mathrm{~km} 2$, Babar dam with a capacity of $54 \mathrm{Mm} 3$ is built to impound the Wadi waters (Figure 1).

\section{Methodology}

The application of multi-variate environmental statistical techniques such as factor analysis (FA), hierarchical ascending classification $(\mathrm{CAH})$ and time series analysis (EN) has increased considerably in recent years for data analysis. and draw useful information [10-12]. Thus, the application of different multivariate statistical techniques can facilitate the interpretation of complex data matrices and the understanding of how to increase the water quality and ecological status of a freshwater system. It also helps to identify possible factors influencing water systems, while being a valuable tool for reliable management of water resources in the area. The objective of this work is to characterize the chemical composition of surface waters and to determine the origin of the chemical elements present using multivariate statistical techniques and the time series. All the statistical computations were made using Excel 2010 (Microsoft Office ${ }^{\circledR}$ ) and STATISTICA 6 (StatSoft, Inc. ®).

\section{Physicochemical analysis}

Monthly surface water was sampled from Wadi Arab and Babar dam, from October 2007 to April 2008 at three stations. The station 1 (S1) and station 2 (S2) are located downstream of urban and industrial discharges and station 3 (S3) is located at the lake of the dam (Figure 1). Total 21 samples ( 7 from each station) were collected. Samples were analyzed for the major ions. The physico-chemical data that were analyzed are $\mathrm{pH}$, temperature of water ( $\mathrm{T})$, Total dissolved solids (TDS), calcium $\left(\mathrm{Ca}_{2}+\right)$, magnesium $\left(\mathrm{Mg}_{2}+\right)$, sodium $(\mathrm{Na}+)$, potassium $(\mathrm{K}+)$, chloride $(\mathrm{Cl}-)$, sulfate $\left(\mathrm{SO}_{4} 2-\right)$, bicarbonates $\left(\mathrm{HCO}_{3}{ }^{-}\right)$, nitrate $\left(\mathrm{NO}_{3}-\right)$ Table 1 . This was achieved using standard methods suggested by the American Public Health Association [13]. The respective ionic balance is generally around $5 \%$.

Table 1: Range, mean, standard deviation (SD), of water quality parameters of the Babar dam during 2007-2008.

\begin{tabular}{|c|c|c|c|c|c|c|c|c|c|c|c|}
\hline & $\mathrm{T}$ & pH & TDS & $\mathrm{Ca}$ & $\mathrm{Mg}$ & $\mathrm{Na}$ & $\mathbf{K}$ & CL & $\mathrm{SO}_{4}$ & $\mathrm{HCO}_{3}$ & $\mathrm{NO}_{3}$ \\
\hline Station & \multicolumn{11}{|c|}{$S 1(n=7)$} \\
\hline Min & 3.7 & 7.6 & 2320 & 224.4 & 148.9 & 811.9 & 6.7 & 255.6 & 880 & 190.3 & 50 \\
\hline Mean & 10.9 & 7.9 & 2837.1 & 261.5 & 168.3 & 908 & 7.7 & 293.2 & 966.1 & 216.6 & 81.4 \\
\hline Max & 20.5 & 8.1 & 3200 & 284.6 & 194.6 & 1019 & 9.6 & 308.9 & 998 & 262.3 & 120 \\
\hline SD & 5,5 & 0.2 & 285.3 & 20.3 & 17.2 & 73 & 0.9 & 16.9 & 41.3 & 23.5 & 27 \\
\hline $\mathrm{Cv}(\%)$ & 51 & 3 & 10 & 7 & 10 & 8 & 11 & 6 & 4 & 10 & 33 \\
\hline Station & \multicolumn{11}{|c|}{$S 2(n=7)$} \\
\hline Min & 3 & 7.5 & 700 & 92.1 & 55.2 & 53.3 & 3.8 & 35.3 & 32.5 & 229.4 & 5 \\
\hline Mean & 10.7 & 7.9 & 917.1 & 110.7 & 72.5 & 66.2 & 5.7 & 57.8 & 38.9 & 262.3 & 10.1 \\
\hline Max & 20.6 & 8.3 & 1250 & 149.7 & 104.4 & 80.8 & 7 & 71 & 46 & 298.9 & 16 \\
\hline SD & 6 & 0.2 & 210.5 & 18.6 & 15.1 & 11.4 & 1.1 & 12.2 & 4.4 & 26.3 & 3.9 \\
\hline Cv (\%) & 56 & 3 & 22 & 17 & 21 & 17 & 18 & 21 & 11 & 10 & 38 \\
\hline Station & \multicolumn{11}{|c|}{ S3 (n=7) } \\
\hline Min & 4 & 7.4 & 1000 & 120.2 & 71.9 & 490.6 & 6.9 & 113.6 & 650 & 222 & 10 \\
\hline Mean & 10.9 & 7.8 & 1557.1 & 147.4 & 93.2 & 574 & 7.6 & 158.4 & 726.3 & 303.1 & 42.9 \\
\hline Max & 20.6 & 8.1 & 1890 & 176.4 & 117.1 & 679.8 & 8.1 & 205.9 & 770 & 384.3 & 90 \\
\hline SD & 57 & 0.3 & 295 & 18.1 & 16.8 & 60.5 & 0.5 & 30.8 & 40.7 & 47.2 & 24.9 \\
\hline $\mathrm{Cv}(\%)$ & 52 & 3 & 19 & 12 & 18 & 11 & 7 & 19 & 6 & 16 & 58 \\
\hline \multicolumn{12}{|c|}{ Total $(n=21)$} \\
\hline Min & 3 & 7.4 & 700 & 92.1 & 55.2 & 53.3 & 3.8 & 35.3 & 32.5 & 190.3 & 5 \\
\hline Mean & 10.8 & 7.8 & 1770.4 & 173.2 & 111.3 & 516.1 & 6.9 & 169.8 & 577.1 & 260.6 & 44.8 \\
\hline Max & 20.6 & 8.3 & 3200 & 284.6 & 194.6 & 1019 & 9.6 & 308.9 & 998 & 384.3 & 120 \\
\hline SD & 5.9 & 0.2 & 862.2 & 68.6 & 45.4 & 359.1 & 1.3 & 101.2 & 404.1 & 50.2 & 36.9 \\
\hline $\mathrm{Cv}(\%)$ & 54 & 3 & 48 & 39 & 40 & 69 & 18 & 59 & 70 & 19 & 82 \\
\hline
\end{tabular}

All values are in $\mathrm{mg} / \mathrm{l}$ except $\mathrm{pH}$ and $\mathrm{T}\left({ }^{\circ} \mathrm{C}\right)$. 


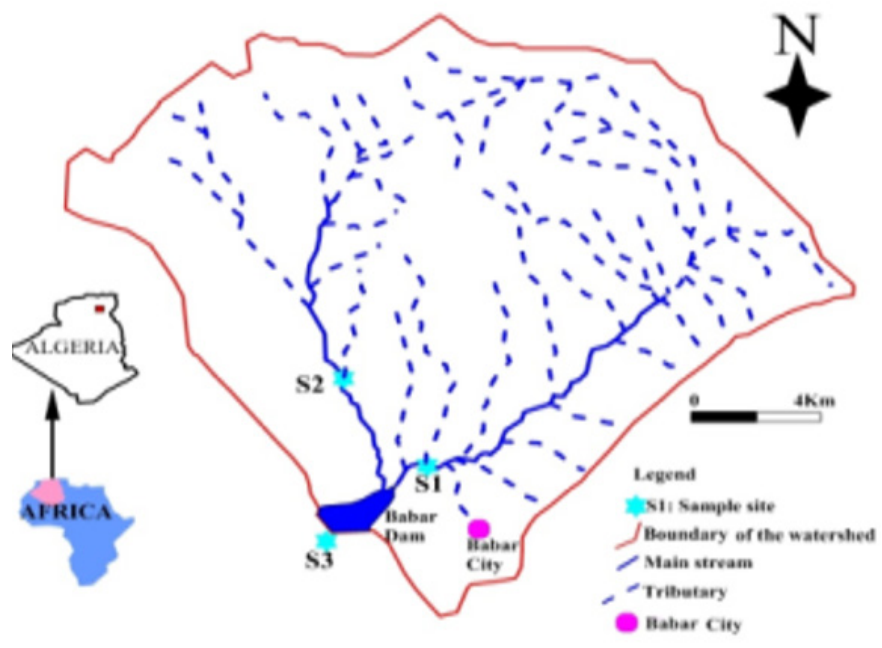

Figure 1: Map of situation of Babar area.

\section{Results and Discussion}

We determined Eleven (11) physicochemical parameters during this study (Table 1). To detrmine the chimical facies of this surface water, the application to diagram of Schoeller Ber- kaloff demonstrated that the sulfat-calcic is dominate for this all échantillons (Figure 2). The source of the calcium can derive from fertilizer nitrogen who participate to the dissolution of carbonates according to reaction 1 and 2 [14].

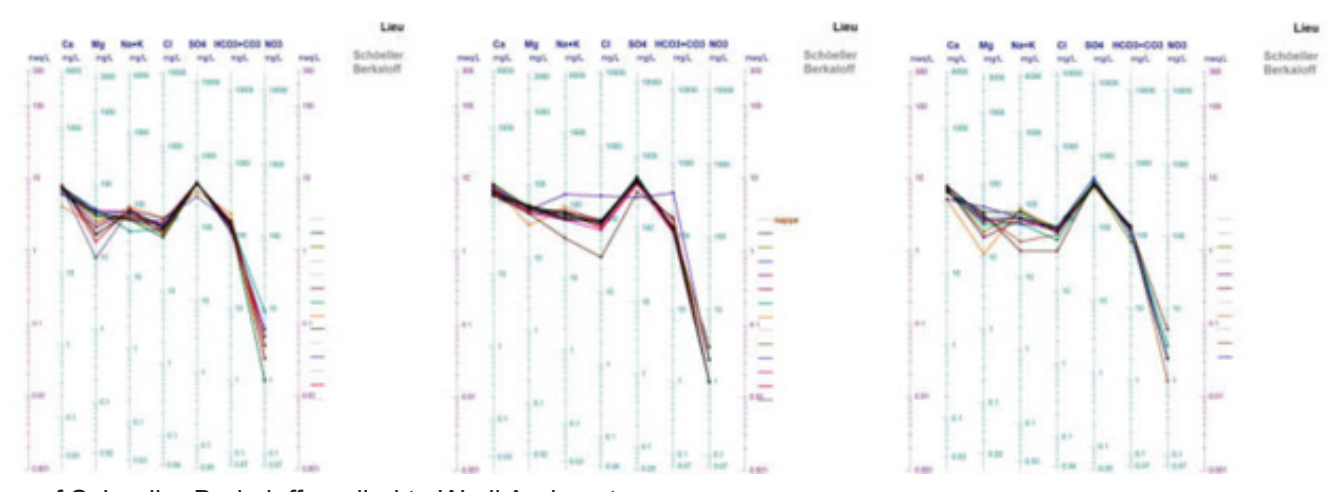

Figure 2: Diagram of Schoeller Berkaloff applied to Wadi Arab water.

$$
\begin{aligned}
& \mathrm{NH}_{4}++2 \mathrm{O}_{2}-------\mathrm{NO}_{3}^{-}+2 \mathrm{H}++\mathrm{H}_{2} 0 \\
& \mathrm{CaCO}_{3}+\mathrm{H}+----------\mathrm{Ca}_{2}++\mathrm{HCO}_{3}^{-}
\end{aligned}
$$

For the sulfate, he can derive from the dissolution of gypsum, anhydrite and halite occur according to reaction 3 [15].

$$
\mathrm{CaSO}_{4}+2 \mathrm{H}_{2} \mathrm{O}-------\mathrm{Ca}_{2}++\mathrm{SO}_{2} 4+2 \mathrm{H}_{2} \mathrm{O}
$$

During the study period, the change in water temperature is similar in the three stations and is largely influenced by the general climate of the region. The low temperatures coincide with the cold period and high temperatures coincide with the warm periods. High temperatures correspond to the warm periods while the low temperatures correspond to the cold ones. $\mathrm{pH}$ value of water samples varied from 7.4 to 8.9 indicating that water is slightly alkaline in nature. In station $\mathrm{S} 2, \mathrm{pH}$ values are higher than the $\mathrm{pH}$ values of the two other stations, this being because of the presence of car- bonate formations thatwe found in this part of the field.

Conventionally, the process of buffering calcite and dolomite, are dominant for the $\mathrm{pH}$ range 6.5 to 7.5 [16]. For the salinity, the S1 with high TDS (2837.1 $\pm 285.3 \mathrm{mg} / \mathrm{l})$, S2 with low TDS $(917 \pm 201.5 \mathrm{mg} / \mathrm{l})$ and S3 with intermediate and average TDS $(1557.1 \pm 295 \mathrm{mg} / \mathrm{l})$ therefore, the salinity can be classified in this order S1 $>\mathrm{S} 3>\mathrm{S} 2$. Higher concentration of TDS observed in S1 and S3, due to the impact of solubility of evaporate element as gypsum, anhydrite and halite $[17,18]$. High concentrations of evaporite elements ( $\mathrm{Na}, \mathrm{K}, \mathrm{Cl}$ and $\mathrm{SO}_{4}$ ) are recorded at $\mathrm{S} 1$ with 908, 7.7, 293.2 and 966.1 respectively. This is mostly due because of the presence of evaporate formations in the concerned area. Another reason for the increase of $\mathrm{Na}, \mathrm{Cl}$ and $\mathrm{SO}_{4}$ concentration is related with the effluents input from the industrial and urban sector [19]. It would also be wise to note that the S3 waters are strongly influenced by 
those of S1. The Ca and Mg content are greater in S1; this is in connection with the dissolution of gypsum and epsomite. As against the HCO3 concentration which is higher in S2 due to dissolution of carbonates formations. The variation of the concentration of NO3 appears to be similar in the three stations. However, we note that the high values are recorded in periods of drought while low concentrations recorded during floods [20].

\section{Statistical analysis}

In this case study, environmental techniques and time series analysis were used to evaluate temporal variations in surface water in the Baber watershed. The sources of water pollution in the Baber watershed could more probably be derived from industrial and urban wastewater, irrigation activity and mineral weathering. The application of Piper diagram for water surface in the region can show three chemical facies. The water type in $\mathrm{S} 1$ is $\mathrm{SO}_{4}-\mathrm{Na}$ for $\mathrm{S} 1$, in $\mathrm{S} 2$ is $\mathrm{HCO}_{3}-\mathrm{Ca}-\mathrm{Mg}$ and is $\mathrm{SO}_{4}$-Ca-Mg water in the dam. These water types are, in fact, a reflection of the predominant influence of gypsum, anhydrite and halite in the Eastern part of study area. The predominant influence of carbonate material is in the western part of study area and mixed water in the dam. In the cluster analysis (R-mode) seven variables were classified into two clusters controlled by $\mathrm{SO}_{4}$. These groups are cluster 1 with evaporate elements: $\mathrm{Na}, \mathrm{Cl}$ and $\mathrm{K}$, cluster 2 with carbonate elements: $\mathrm{Ca}, \mathrm{Mg}$ and HCO3. In Q-mode, 21 samples were classified into three groups. The first group is made up by the samples belonging to the station $\mathrm{S} 1$. Second group 2 is represented by the samples belonging to the station S2. The third group is made up by the samples belonging to the station S3. In PCA, the two main principal components explain $87.2 \%$ of the total variance. Time series analysis also provided the same results. The autocorrelation shows that TDS, $\mathrm{Ca}, \mathrm{Mg}, \mathrm{Na}, \mathrm{K}, \mathrm{Cl}$ and $\mathrm{HCO}_{3}$ have a strong linear interrelationship, and they are subjected to periodically changing sources. In fact, $\mathrm{NO}_{3}$ and $\mathrm{SO}_{4}$ are affected by anthropogenic sources, urban action and geological condition. Spectral density functions of $\mathrm{Ca}, \mathrm{Mg}, \mathrm{Na}, \mathrm{Cl}$ and $\mathrm{HCO}_{3}$ has almost similar trend with TDS. It suggests that TDS was affected by these elements and that TDS plays a more vital role on the surface water quality. But the multiple peaks of the spectral density functions of $\mathrm{pH}, \mathrm{K}, \mathrm{SO}_{4}$ and $\mathrm{NO}_{3}$ resulted from the human activity, fertilizer and domestic sewage. The cross-correlations of $\mathrm{Ca}, \mathrm{Mg}, \mathrm{Na}, \mathrm{Cl}$ and $\mathrm{SO}_{4}$ have very similar trend with TDS and $\mathrm{K}$ have similar pattern as NO3. It suggests that five components are the controlling factors of the TDS. $\mathrm{K}$ and $\mathrm{NO}_{3}$ represent a negative correlation with TDS, it resulted from the human activity, fertilizer and domestic sewage inputs from the tributaries of Wadi Arab. The results of this study clearly demonstrate the usefulness of the multivariate statistical analysis in hydrochemistry.

\section{Conclusion}

To quantify pollution, environmental techniques and time series analyzes were used to assess temporal variations in surface water in the Babar watershed. Sources of Water Pollution in the
Babar Watershed Could Be Further Derived from Industrial and Urban Wastewater, Irrigation Activities and Mineral Storms. In the group analysis ( $\mathrm{R}$ mode), seven variables were classified into two groups controlled by $\mathrm{SO}_{4}$. These groups are group 1 with evaporated elements: $\mathrm{Na}, \mathrm{Cl}$ and $\mathrm{K}$, group 2 with carbonate elements: $\mathrm{Ca}, \mathrm{Mg}$ and $\mathrm{HCO}_{3}$. In $\mathrm{Q}$ mode, 21 samples were classified into three groups. The first group consists of the samples belonging to the S1 station. The second group 2 is represented by the samples belonging to the station S2. The third group consists of the samples belonging to the S3 station. In the ACP, the two main components explain $87.2 \%$ of the total variance. Time series analysis also yielded the same results. The autocorrelation shows that TDS, $\mathrm{Ca}, \mathrm{Mg}, \mathrm{Na}, \mathrm{K}, \mathrm{Cl}$ and $\mathrm{HCO}_{3}$ have a strong linear interrelation, and they are subjected to periodically changing sources. Indeed, $\mathrm{NO}_{3}$ and $\mathrm{SO}_{4}$ are affected by anthropogenic sources, urban action and geological status. The spectral density functions of $\mathrm{Ca}, \mathrm{Mg}, \mathrm{Na}, \mathrm{Cl}$ and $\mathrm{HCO}_{3}$ have an almost similar trend with TDS. He suggests that TDS has been affected by these elements and that the TDS plays a more vital role in the quality of surface water. But the multiple peaks of the spectral density functions of $\mathrm{pH}, \mathrm{K}, \mathrm{SO}_{4}$ and $\mathrm{NO}_{3}$ result from human activity, fertilizers and domestic wastewater. The cross-correlations of $\mathrm{Ca}, \mathrm{Mg}$, $\mathrm{Na}, \mathrm{Cl}$ and $\mathrm{SO}_{4}$ have a very similar tendency with TDS. By cons $\mathrm{K}$ has a model similar to $\mathrm{NO}_{3}$. He suggests that five components are the controlling factors of TDS. $\mathrm{K}$ and $\mathrm{NO}_{3}$ are negatively correlated with TDS, resulting from human activity, fertilizers and domestic sewage from tributaries of Oued El Arab. The results of this study clearly demonstrate the utility of multivariate statistical analysis in hydrochemistry.

\section{Acknowledgement}

None.

\section{Conflict of Interest}

No conflict of interest.

\section{References}

1. TWAS (2002) Safe drinking water, the need, the problem, solutions and action plan. 3rd World Academic of sciences, Italy, pp. 8-12.

2. Lamikanra A (1999) Essential Microbiology for students and Practitioners of Pharmacy, Medicine and Microbiology. 2nd Edn. Amkra books, $406 \mathrm{p}$.

3. Sonawane VY, Khole AM (2010) Water quality of some drinking waters in Parbhani city: A case study. J Chem Pharmaceut Res 2: 104-107.

4. Ayeni AO, Balogun II, Soneye ASO (2011) Seasonal assessment of physico-chemical concentration of polluted urban River: A case of Ala River in south western Nigeria. Res J Environ Sci 5: 21-35.

5. Bhardwaj RM (2005) Water quality monitoring in India achievements and constraints. International work session on water statistics, Vienna 2: 20-22.

6. Ahmed TK, Tahir SS, Rauf N (2004) Bacteriological analysis of water collected from different dams of Rawalpindi/Islamabad region in Pakistan. Pak J Biol Sci 7(5): 662-666.

7. GWP (Global Water Partnership) (2009) A handbook for Integrated Water Resources Management in Basins. 
8. Yang H, Zehnder (2007) A Virtual Water: An unfolding concept in integrated water resources management, water resources Research 43(12): W12301.

9. World Meteorological Organization (WMO) (2012) Technical Material for Water Resources Assessment (WMO-No. 1095), Geneva.

10. Shihab AS, Abdul Baqi YT (2010) Multivariate analysis of ground water quality of Makhmor plain/north Iraq. Damascus University Journal 26: 19-26.

11. Batayneh A, Zumlot T (2012) Multivariate statistical approach to geochemical methods in water quality factor identification; application to the shallow aquifer system of the Yarmouk Basin of north Jordan Research Journal of Environmental and Earth Sciences 4: 756-768.

12. Laaksoharju M, Skarman C, Skarman E (1999) Multivariate mixing and mass balance (M3) calculations, a new tool for decoding hydrogeochemical information. Applied Geochemistry 14: 861- 871.

13. American Water Works Association and Water Environment Federation (APHA) (2005) Standard methods for the examination of water and wastewater. Washington, DC 20001-3710.

14. Boudoukha A, Bouguerne A, Mebarkia A (2014) Impact du changement climatique et de l'activité anthropique sur la qualité des eaux du barrage Ain Zada. Algérie. International journal for environnent \& global climat change 2: 74- 85 .
15. Stumm W, Morgan JJ (1996) Aquatic chemistry-chemical equilibria and rates in natural waters. 3rd ed. New York: Wiley \& Sons.

16. Geller W, Friese K, Herzsprung P, Kringel R, Schultze M (2000) Limnology of sulphuracidic mining lakes. II Chemical properties: The main constituents and buffering systems. Verha Inter Ver Limnol 27: 2475-2479.

17. Nas B, Berktay A (2010) Groundwater quality mapping in urban groundwater using GIS. Environmental Monitoring and Assessment 8: 215-227.

18. Pacini N, Donabaum K, De Villeneuve PH, Konecny R, Pineschi G, et al. (2013) Water-quality management in a vulnerable large river: the Nile in Egypt. International Journal of River Basin Management 11: 205-219.

19. Kura NU, Ramli MF, Ibrahim S, Sulaiman WNA, Aris AZ (2014) An integrated assessment of seawater intrusion in a small tropical island using geophysical, geochemical, and geostatistical techniques. Environmental Science and Pollution Research 21(11): 7047-7064.

20.Sæbø HV (1991) Statistical analysis of effects of measures against agricultural pollution. Environmental Monitoring and Assessment 17: $137-146$ 